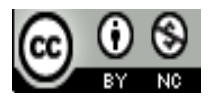

Jurnal Pendidikan Matematika Indonesia is licensed under

A Creative Commons Attribution-Non Commercial 4.0 International License.

\title{
KEMAMPUAN PEMECAHAN MASALAH MATEMATIKA BERDASARKAN GAYA KOGNITIF, KEMANDIRIAN BELAJAR, DAN GENDER (Studi Kasus Mahasiswa Prodi Pendidikan Matematika FKIP UNIVERSITAS DR. SOETOMO)
}

\author{
Sucipto $^{1)}$, Ahmad Hatip ${ }^{2)}$ \\ 1) Universitas Dr. Soetomo, Surabaya, Indonesia \\ E-mail: sucipto@unitomo.ac.id \\ 2) Universitas Dr. Soetomo, Surabaya, Indonesia \\ E-mail: ahmad.hatip@unitomo.ac.id
}

\begin{abstract}
Abstrak. Penelitian ini bertujuan untuk menguji kemampuan memecahkan masalah matematis mahasiswa berdasarkan gaya kognitif, tingkat kemandirian belajar, dan gender. Penelitian menerapkan jenis pendekatan kuantitatif dengan metode expose facto. Sampel penelitian berjumlah 53 mahasiswa Prodi Pendidikan Matematika dengan menggunakan teknik purposive sampling. Pengumpulan data menggunakan metode tes, inventori, dan angket dengan instrumen yang valid. Teknis analisis data menggunakan statistik parametrik dengan uji t (t-test) dan non parametrik uji Mann Whitney. Hasil penelitian menunjukkan terdapat perbedaan kemampuan memecahkan masalah matematis mahasiswa berdasarkan gaya kognitif dan berdasarkan tingkat kemandirian belajar pada mahasiswa, namun tidak terdapat perbedaan berdasarkan gender.
\end{abstract}

Kata Kunci: kemampuan pemecahan masalah, gaya kognitif, kemandirian belajar, gender

\section{PENDAHULUAN}

Abad ke-21 ditandai dengan kehidupan global yang telah membuka tantangan sekaligus peluang baru bagi peran pendidikan untuk meningkatkan kompetensi lulusannya. Kay (2010) yang dikutip kembali oleh (Wismath \& Orr, 2015), mengemukakan bahwa keterampilan inti sumber daya manusia (SDM) abad ke-21 mencakup keterampilan pemecahan masalah, pemikiran kritis, kreativitas, inovasi, kolaborasi, dan komunikasi. Hal ini diperkuat dalam $21^{\text {st }}$ Century Partnership Learning Framework bahwa sejumlah keterampilan dan kompetensi yang dibutuhkan sebagai berikut: 1) pemikiran kritis dan penyelesaian masalah, 2) komunikasi dan kolaborasi, 3) kreativitas dan inovasi, 4) literasi teknologi informasi dan komunikasi, 5) keterampilan belajar kontekstual, dan 6) keterampilan literasi informasi dan media (Badan Standar Nasional Pendidikan, 2010).

Keterampilan pemecahan masalah merupakan bagian dari kompetensi yang harus dimiliki dan dikembangkan individu sebagai bekal menghadapi permasalahan yang semakin kompleks. Pemecahan masalah menjadi aktivitas manusia yang bersifat mendasar dan dominan dibutuhkan untuk mengatasi segala bentuk permasalahan hidup. Pemecahan masalah menjadi salah satu jenis pengolahan kognitif penting bahkan menjadi proses kunci dalam pembelajaran (Schunk, 2012). Untuk itu dibutuhkan cara merespon masalah tersebut sehingga menjadi mudah untuk memecahkan masalah tersebut (Solso, Maclin, \& Maclin, 2008). Untuk membantu individu dalam menemukan, merumuskan, memecahkan masalah serta mengambil keputusan yang tepat dibutuhkan aktivitas berpikir. Wismath \& Orr (2015) menggarisbawahi bahwa peningkatan keterampilan pemecahan masalah bagian penting dari 


\section{- - - Jurnal Pendidikan Matematika Indonesia \\ Volum 5 Nomor 1 bulan Maret 2020 Page 1 - 6 \\ p-ISSN: 2477-5967 e-ISSN: 2477-8443}

keterampilan metakognitif. King et al., (1998); Brookhart (2007), mengemukakan bahwa untuk menyelesaikan masalah individu perlu menerapkan beberapa proseshigher order thinking yakni pemecahan masalah. Sani (2016) menambahkan bahwa untuk proses memecahkan masalah membutuhkan kemampuan berpikir divergen.

Berdasarkan kajian, kompetensi lulusan secara umum belum berbanding lurus dengan tuntutan keterampilan abad ke-21. Lulusan jenjang sekolah menengah dan pendidikan tinggi belum menunjukkan kompetensi yang diharapkan. Beberapa kompetensi yang belum optimal diantaranya: 1) komunikasi, 2) berpikir kritis dan pemecahan masalah, 3) etika bekerja dan profesionalisme, 4) keterampilan kolaboratif, 5) bekerja antar kelompok berbeda, 6) memanfatkan teknologi, dan 7) pengelolaan proyek dan leadership(Trilling \& Fadel, 2009).

Hasil survey Programme for International Student Assesment (PISA) yang dilakukan tiga tahun sekali dalam bidang literasi membaca, kemampuan matematika, dan kemampuan sains 2015, Indonesia menempati ranking 63 dari 72 negara peserta (OECD, 2016). Nilai rerata matematika mencapai 386 dibawah rerata internasional sebesar 490. Faktor penyebab rendahnya peringkat Indonesia karena kurangnya kemampuan pemecahan masalah non routine.Pebelajar Indonesia terbiasa mengerjakan masalah routine yang berada pada tingkatan 1 dan 2 dari 6 level yang diujikan dalam PISA.Permasalahan pada tingkat sekolah berlanjut pada jenjang perguruan tinggi. Pada pendidikan tinggi ditemukan berbagai permasalahan kualitas lulusan, diantaranya kurangnya higher order thinking termasuk di dalamnya kemampuan pemecahan masalah(Kemenristekdikti, 2016).

Blanca (1980) menegaskan bahwa kemampuan pemecahan masalah merupakan kompetensidasar dan umum dari proses belajar mengajar matematika serta proses utama dalam kurikulum matematika. Pernyataan tersebut juga dikuatkan NationalCouncilof TeacherofMathematics(2000) yang dikutip kembali Cahyani dan Setyawati (2016) menegaskan ada lima kompetensi standard utama dalam pembelajaran matematika yakni kemampuan pemecahan masalah, kemampuan penalaran, kemampuan koneksi, kemampuan komunikasi dan kemampuanrepresentasi. Implikasi dari pendapat tersebut kemampuan pemecahan masalah perlu dimiliki oleh pebelajar mulai bangku sekolah hingga di perguruan tinggi. Bagi mahasiswa prodi matematika, kemampuan pemecahan masalah merupakan faktor penting yangharusdikuasai, dikembangkan, dan diintegrasikan padasejumlahmateriyangsesuai.

Keberhasilan proses pembelajaran dalam peningkatan kemampuan pemecahan masalah matematis harus memperhatikan variable metode pembelajaran, kondisi pembelajaran, dan hasil pembelajaran. Pendidikan harus berubah ke arah cara yang memungkinkan pebelajar untuk memperoleh pemikiran kreatif, pemecahan masalah yang fleksibel, kolaboratif dan keterampilan inovatif yang dibutuhkan dalam bidang kerja dan kehidupan seharihari(Pacific Policy Research Center, 2010). Beberapa unsur dari dimensi kondisi pembelajaran diantaranya tujuan dan karakteritik bidang studi serta karakteristik pebelajar (Degeng, 2013). Karakteristik pebelajar mencakup aspekaspek pebelajar seperti: motivasi, kemandirian belajar, sikap, bakat, minat, gaya kognitif, kecerdasan berpikir, entry behavioral dan lainnya. Lebih lanjut Degeng menegaskan bahwa karakteristik pebelajar berpengaruh terhadap pemilihan strategi pengelolaan khususnya komponen strategi pembelajaran.

Gaya kognitif merupakan bagian dari variabel kondisi belajar yang perlu diperhatikan dalam mendesain maupun menerapkan proses pembelajaran seperti mendesainisi bidang kajian, tujuan yang diharapkan, serta strategi pembelajaran. Penelitian yang memfokuskan pada hubungan antara gaya kognitif dan strategi pembelajaran di Cina menyimpulkan bahwa gaya kognitif memiliki pengaruh yang signifikan terhadap pilihan strategi pembelajaran pembelajar (Shi, 2011). Messick (dalam Schunk, 1996) menjelaskan bahwa gaya kognitif mempengaruhi kognisi dan perilaku pebelajar. Perbedaan gaya kognitif berkaitan dengan perbedaan individu dalam pembelajaran dan penerimaan dari berbagai bentuk pengajaran. Suasana belajar akan tercipta dengan baik apabila menyesuaikan proses kognitif atau perkembangan kognitif pebelajar (Uno, 2006). Penelitian pada 300 mahasiswa di India menemukan bahwa ada perbedaan signifikan dan hubungan positif antara gaya kognitif dan kemampuan pemecahan masalah (Jena, 2014).

Kemandirian belajar berhubungan dengan self regulated learning,merupakan salah karakteristik pebelajar penting yang perlu diperhatikan dalam pembelajaran. Pebelajar yang mempunyai kemandirian belajar tinggi akan mempunyai kemampuan memecahkan masalah lebih tinggi. Seseorang yang mempunyai kemandirian tinggi biasanya akan mempunyai kesadaran yang tinggi untuk melakukan sesuatu yang ia yakini. Kemandirian belajar meningkat ketika pebelajar aktif belajar, mau mengontrol sendiri terhadap berbagai hal yang sudah dilakukan, melakukan mengevaluasi dan menyusun rencanakegiatan yang lebih baik dalam pembelajaran. Studi yang dilakukan Bey (2013) menemukan bahwa kemandirian belajar matematika berpengaruh secara signifikan terhadap hasil belajar matematika.

Gender dewasa ini semakin banyak dijadikan sebagai objek penelitian.Variabel ini dianggap penting karena struktur otak pria dan wanita mempunyai perbedaan. Pasiak (2005: 91) mengemukakan bahwa struktur otak pria dan wanita memiliki perbedaan pada anatomi yang berimplikasi pada perbedaan cara dan gaya melakukan sesuatu termasuk belajar. Pada jenjang pendidikan menengah dan tinggi, pebelajar pria dalam menyelesaikan suatu masalah lebih senang ketika mendapati sesuatu yang baru atau menantang. Elliott (2000) berpendapat bahwa pebelajar pria lebih mampu dalam bidang sains dan matematika, sedangkan pebelajar wanita akan lebih baik pada aktivitas yang lebih feminim seperti bidang seni dan musik. Santrock (2007) menggarisbawahi bahwa faktor psikis pada gender berpengaruh terhadap prestasi belajar. Lebih lanjut dikemukakan bahwa gender merupakan dimensi psikologis 


\section{A - - - Jurnal Pendidikan Matematika Indonesia \\ Volum 5 Nomor 1 bulan Maret 2020 Page 1 - 6 \\ p-ISSN: 2477-5967 e-ISSN: 2477-8443}

dan sosiokultural.

Penelitian yang dilakukan oleh Fitriani menyatakan bahwa gender menunjukkan hubungan dengan yang rendah dengan kemampuan pemecahan masalah. Temuan lainnya menunjukkan perbedaan yang signifikan antara kemampuan pebelajarpria dan wanita dalam pemecahan masalah.Hasil studi yang berbeda dilakukan Murtafiah (2018) menyatakanbahwa gender tidak berpengaruh secara nyata terhadap kemampuan pemecahan masalah matematika.

Berpijak dari beberapa kajian empiris sebelumnya, penelitian ini bertujuan untuk mengetahui kemampuan pemecahan masalah matematika berdasarkan gaya kognitif, kemandirian belajar, dan gender pada mahasiswa Prodi Pendidikan Matematika Fakultas Keguruan dan Ilmu Pendidikan (selanjutnya disingkat FKIP) Universitas Dr. Soetomo.

Penelitian diharapkan memberikan manfaat khususnya kepada pembelajar agar dalam menumbuhkembangkan kemampuan pemecahan masalah selain menerapkan strategi pembelajaran yang relevan juga perlu memperhatikan karakteristik mahasiswa, diantaranya: gaya kognitif, kemandirian belajar, dan gender.

Berdasarkan kajian empiris sebelumnya yang relevan, hal yang berbeda pada penelitian ini berusaha mengkaji kemampuan pemecahan masalah berdasarkan perbedaan gaya kognitif sekaligus dari perbedaan gender.

\section{METODE PENELITIAN}

Penelitian ini menerapkan jenis paradigma kuantitatif. Variabel-variabel yang diteliti merupakan variabel yang sudah dimiliki oleh mahasiswa Prodi Pendidikan Matematika FKIP Universitas Dr. Soetomo. Populasi penelitian adalah mahasiswa Prodi Pendidikan Matematika FKIP Universitas Dr. Soetomo sebagai mahasiswa aktif pada semester genap 2018/2019. Sampel penelitian ini sejumlah 53 mahasiswa yang berasal dari berbagai semester Prodi Pendidikan Matematika FKIP Universitas Dr. Soetomo.Teknik sampling menggunakan teknik purposive sampling.

Metode mengumpulkan data dari subjek penelitian digunakan menggunakan: (1) metode tes untuk mengukur kemampuan memecahkan masalah matematika pada masingmasing individu,Untuk mengukur kemampuan memecahkan masalah matematika pada subjek penelitian digunakan instrumen soal tes. Soal tes berbentuk uraian sebanyak 5 butir yang yang sudah tervalidasi. (2) metode inventori,jenis inventori yang digunakan adalah cognitive style inventory (CSI) digunakan untuk mengukur cara berpikir, menilai, mengingat, menyimpan informasi, pengambilan keputusan dan hubungan interpersonal. Teknik ini digunakan untuk mengukur atau menentukan dimensi gaya kognitif FD atau FI pada masing-masing individu, Instrumen yang digunakan pada penelitian ini disebut skala gaya kognitif dengan bentuk skala Likert. Instrumen skala gaya kognitif yang digunakan pada penelitian ini berjumlah 40 item yang sudah tervalidasi baik oleh ahli dan uji empiris, diadopsi dari Sucipto (2019). (3) angketdigunakan untuk mengetahui tingkat kemandirian belajar mahasiswa. Angket disusun dengan menggunakan skala Likert untuk mengukur persepsi, sikap individu atau kelompok mengenai kemandirian belajar mahasiswa. Pengisian angket menggunakan checklist dengan empat pilihan jawaban. Angket terdiri dari 19 butir yang sudah tervalidasi.

Untuk menguji hipotesis digunakan teknik analisis data berupa statistik parametrik uji t-test dan statistik non parametrik uji Mann Witney dengan bantuan SPSS.

\section{HASIL DAN PEMBAHASAN}

Data yang sudah terkumpul selanjutnya dilakukan analisis data dengan statistik untuk menguji masing-masing rumusan hipotesis. Langkah-langkah analisis data dipaparkan sebagai berikut.

1. Perbedaan Kemampuan Memecahkan Masalah Matematika Mahasiswa Gaya Kognitif FD dengan Gaya Kognitif FI

TABEL I UJI NORMALITAS

\begin{tabular}{ccc}
\hline \multirow{2}{*}{ GPaya Kognitif } & \begin{tabular}{c} 
Kolomogorov \\
Smirnov \\
\cline { 2 - 3 }
\end{tabular} & FI \\
\hline \multirow{2}{*}{ KPM } & GD & 0.000 \\
\cline { 2 - 3 } & & 0.040 \\
\hline
\end{tabular}

Pada uji Kolmogorov-Smirnov nampak bahwa nilai sig. Kemampuan Pemecahan Masalah (KPM) gaya kognitif FI adalah $0.000<0.05$. Begitu juga nilai sig. KPM gaya kognitif FD sebesar $0.040<0.05$ yang berarti bahwa $\mathrm{H}_{0}$ ditolak, sehingga data tidak normal. Karena data tidak normal, maka uji berikutnya yang digunakan adalah Mann Whitney.

TABEL II

UJI HOMOGENITAS VARIAN

\begin{tabular}{cccc}
\hline & & Levene & Sig. \\
\hline KPM & $\begin{array}{c}\text { Based on } \\
\text { Mean }\end{array}$ & 0.036 & 0.850 \\
\hline
\end{tabular}

Pada uji Lavene di Tabel II nampak nilai sig. sebesar $0.850>0.05$ yang berarti $\mathrm{H}_{0}$ diterima yaitu bahwa data bersifat homogen. Mengingat data tidak normal meskipun data homogen maka uji hipotesis menggunkan teknik Mann Whitney dengan hasil sebagai berikut.

TABEL III

UJI MANN WHITNEY TEST

\begin{tabular}{cc}
\hline & KPM \\
\hline Mann-Whitney U & 50.000 \\
\hline Sig. & 0.000 \\
\hline
\end{tabular}

Pada uji Mann Whitney di Tabel III nampak bahwa nilai sig. sebesar $0.000<0.05$ sehingga $\mathrm{H}_{0}$ ditolak, yaitu terdapat perbedaan KPM matematika mahasiswa yang mempunyai gaya kognitif FI dengan gaya kognitif FD. Hasil ini menguatkan penelitian yang dilakukan Jena (2014) pada 300 pebelajar di India bahwa ada perbedaan signifikan dan 
hubungan positif antara gaya kognitif dan kemampuan pemecahan masalah. Selanjutnya untuk mengetahui jenis gaya kognitif mahasiswa yang lebih unggul dalam KPM matematika dikemukakan pada tabel berikut.

TABEL IV

PERBEDAAN MEAN KPM BERDASARKAN GAYA KOGNITIF

\begin{tabular}{lll|c|c|c}
\hline & $\begin{array}{l}\text { Gaya } \\
\text { Kognitif }\end{array}$ & N & $\begin{array}{c}\text { Rata- } \\
\text { rata }\end{array}$ & $\begin{array}{l}\text { Standar } \\
\text { Deviasi }\end{array}$ & Eror \\
\hline \multirow{2}{*}{ KPM } & FI & 24 & 88.9583 & 12.33404 & 2.51768 \\
\cline { 2 - 7 } & FD & 29 & 61.2069 & 13.06954 & 2.42695 \\
\hline
\end{tabular}

Pada tabel perbedaan mean KPM berdasar gaya kognititf di tabel IV menunjukkan bahwa mean nilai KPM mahasiswa gaya kognitif FI lebih unggul secara signifikan dibanding FD. Hal ini dapat dijelaskan bahwa mahasiswa yang mempunyai gaya kognitif FI pada umumnya memiliki kemampuan analisis matematika yang lebih tinggi dalam hal penerimaan dan pemrosesan informasi (analytical thinkers). Dengan kemampuan analisis yang tinggi individu gaya kognitif FI mempunyai KPM dibanding individu gaya kognitif FD.

2. Perbedaan Kemampuan Memecahkan Masalah Matematis Berdasarkan Tingkat Kemandirian Belajar pada Mahasiswa

TABEL V UJI NORMALITAS

\begin{tabular}{ccc}
\hline \multirow{2}{*}{ Kemandirian } & \multicolumn{1}{c}{$\begin{array}{c}\text { Kolomogorov } \\
\text { Smirnov }\end{array}$} \\
\cline { 2 - 3 } & & Sig. \\
\cline { 2 - 3 } & Atas & 0.86 \\
\hline \multirow{2}{*}{ Kawah } & 0.60 \\
\hline
\end{tabular}

Pada tabel uji Normalitas di Tabel V terlihat bahwa nilai sig. KPM berdasarkan kemandirian level atas sebesar $0.086>$ 0.05 sehingga $\mathrm{H}_{0}$ diterima yaitu bahwa data normal. Begitu juga nilai sig. KPM berdasarkan kemandirian level bawah sebesar $0.060>0.05$ sehingga $\mathrm{H}_{0}$ diterima yaitu bahwa data normal.

TABEL VI

UJI HOMOGENITAS DAN UJI T

\begin{tabular}{ccccc}
\hline \multicolumn{3}{c}{ Lavene Tes } & & \multicolumn{2}{c}{$\begin{array}{c}\text { Uji Independen } \\
\text { sampel t-tes }\end{array}$} \\
\hline & $\mathrm{F}$ & Sig. & $\mathrm{T}$ & Sig. \\
\hline Kemandirian & 0.694 & 0.409 & 5.079 & 0.000 \\
\hline
\end{tabular}

Pada Tabel VI kolom Levene's test terlihat bahwa nilai sig. adalah $0.409>0.05$ yang berarti bahwa $\mathrm{H}_{0}$ diterima sehingga data bersifat homogen. Mengingat uji prasyarat sudah terpenuhi maka untuk uji yang akah digunakan adalah uji independen sampel t-test. Berdasarkan Tabel VI terlihat bahwa pada kolo uji independen sampel t-test nilai signifikansi adalah $0.000<0.05$ sehingga $\mathrm{H}_{0}$ ditolak sehingga disimpulkan terdapat perbedaan KPM matematika berdasarkan tingkat kemandirian belajar. Mahasiswa yang mempunyai kemandirian belajar level atas mencapai KPM matematika lebih unggul dibanding level bawah. Mahasiswa yang mempunyai kemandirian belajar level atas menunjukkan tentang pemikiran, membuat rencana dan mengambil tindakan serta mengambil keputusan sehingga mendapatkan KPM yang diharapkan. Hasil penelitian selaras dengan penelitian Dewi dan Suhendri (2017) bahwa terdapat pengaruh yang nyata antara kemandirian belajar terhadap kemampuan pemecahan masalah (KPM) matematika. Mahasiswa yang mempunyai kemandirian baik akan bersikap mandiri dalam mengadapi masalah. Sebaliknya, mahasiswa yang tidak mempunyai kemandirian/kemandirian rendah maka tidak akan mampu mengahadapi masalah. Sikap kemandirian ini sangat dibutuhkan oleh mahasiswa dalam memecahkan masalah matematika.

3. Perbedaan Kemampuan Memecahkan Masalah Matematis Berdasarkan Gender

TABEL VII

UJI NORMALITAS

\begin{tabular}{ccc}
\hline \multirow{2}{*}{ Gender } & \multicolumn{1}{c}{$\begin{array}{c}\text { Kolomogorov } \\
\text { Smirnov }\end{array}$} \\
\cline { 2 - 3 } & Pria & Sig. \\
\cline { 2 - 3 } & Wanita & 0.52 \\
\hline
\end{tabular}

Pada tabel uji normalitas di Tabel VII terlihat bahwa nilai sig. KPM matematis pria adalah $0.052>0.05$ sehingga $\mathrm{H}_{0}$ diterima, yang artinya data normal. Begitu juga nilai sig. KPM matematis wanita adalah $0.200>0.05$ sehingga $\mathrm{H}_{0}$ diterima, yang artinya data normal.

TABEL VIII

UJI HOMOGENITAS DAN UJI T

\begin{tabular}{ccccc}
\hline & & & \multicolumn{2}{c}{$\begin{array}{c}\text { Uji Independen } \\
\text { sampel t-tes }\end{array}$} \\
\hline & $\mathrm{F}$ & Sig. & $\mathrm{T}$ & Sig. \\
\hline Gender & 0.689 & 0.410 & 0.529 & 0.599 \\
\hline
\end{tabular}

Pada tabel VIII kolom Levene's test terlihat bahwa nilai sig. adalah $0.410>0.05$ sehingga $\mathrm{H}_{0}$ diterima yang berarti bahwa data homogen. Langkah berikutnya adalah uji hipotesis yaitu digunakan uji independen sampel t-test. Berdasarkan tabel VIII terlihat bahwa nilai sig. sebesar $0.599>0.05$ sehingga $\mathrm{H}_{0}$ diterima yaitu tidak terdapat perbedaan KPM matematis berdasarkan gender. Walaupun menunjukkan perbedaan nilai KPM antara mahasiswa pria dan wanita namun secara statistik tidak signifikan. Argumentasi yang yang mendukung kesimpulan tersebut ada variabel lain yang lebih berpengaruh pada diri mahasiswa selain gender terhadap KPM. Hal ini sejalan dengan penelitian (Hardy, Bambang Hudiono, 2015) menyatakan bahwa tidak ada perbedaan skor KPM siswa pria dan perempuan. Meskipun secara struktur dan kemampuan tata 


\section{-}

ruang, pria lebih baik dari perempuan, namun itu belum cukup dijadikan sebagai dasar bahwa gender berpengaruh dalam memecahkan masalah matematika. Dalam memecahkan masalah matematika dibutuhkan kompetensi utuh yang harus dikuasai oleh seseorang untuk mampu memecahkan masalah matematika.

4. Perbedaan Kemampuan Memecahkan Masalah Matematis Mahasiswa Gaya Kognitif FD Berdasarkan Gender

TABEL IX UJI NORMALITAS

\begin{tabular}{ccc}
\hline \multirow{2}{*}{ KPM FD } & \multicolumn{1}{c}{ Shapiro-Wilk } \\
\cline { 2 - 3 } & & Sig. \\
\cline { 2 - 3 } & Pria & 0.195 \\
\hline \multirow{2}{*}{ Kanita } & 0.153 \\
\hline
\end{tabular}

Pada Tabel uji normalitas di tabel VIII pada kolom Shapiro-Wilk terlihat bahwa nilai signifikan KPM matematis mahasiswa yang mempunyai gaya kognitif FD laki-laki sebesar $0.195>0.05$ sehingga diterima $\mathrm{H}_{0}$ yaitu bahwa data normal. Begitu juga nilai signifikan KPM matematis mahasiswa yang mempunyai gaya kognitif FD wanita sebesar $0.005 \geq 0.05$ sehingga diterima $\mathrm{H}_{0}$ yaitu bahwa data normal.

TABEL $X$ UJI HOMOGENITAS DAN UJI T

\begin{tabular}{ccccc}
\hline & & & \multicolumn{2}{c}{$\begin{array}{c}\text { Uji Independen } \\
\text { sampel t-tes }\end{array}$} \\
\hline & $\mathrm{F}$ & Sig. & $\mathrm{T}$ & Sig. \\
\hline Gender & 1.090 & 0.306 & 1.464 & 0.155 \\
\hline
\end{tabular}

Pada tabel uji homogenitas di tabel $\mathrm{X}$ nampak pada Levenes's Test bahwa nilai sig. adalah $0.306>0.05$ sehingga $\mathrm{H}_{0}$ diterima yaitu data homogen. Mengingat uji prasyarat sudah terpenuhi maka untuk uji hipotesis digunakan uji independen sampel t-test. Berdasarkan tabel X nampak pada kolom uji independen sampel t-tes bahwa nilai sig. adalah $0.155>0.05$ sehingga $\mathrm{H}_{0}$ diterima yang artinya tidak terdapat perbedaan KPM matematis mahasiswa yang mempunyai gaya kognitif FD berdasarkan gender. Artinya KPM pada mahasiswa yang mempunyai gaya kognitif FD menunjukkan kesamaan antara pria dan wanita. Dalam hasil analisis sebelumnya telah diketahui bahwa gender tidak berpengaruh dalam KPM matematika mahasiswa. penelitian (Hardy, Bambang Hudiono, 2015) yang menyatakan bahwa tidak ada perbedaan KPM siswa pria dan wanita. Hasil itu secara umum telah memberikan gambaran bahwa gender (tanpa melihat apakah seseorang punya gaya kognitif FI atau FD) telah memberikan hasil bahwa tidak berpengaruh terhadap KPM matematika. Pada bagian ini lebih spesifik dihasilkan sebuah gambaran bahwa pria dan wanita gaya kognitif FD ternyata tidak berpengaruh terhadap KPM matematika.
5. Perbedaan Kemampuan Memecahkan Masalah Matematis Mahasiswa Gaya Kognitif FI Berdasarkan Gender

TABEL XI

UJI NORMALITAS

\begin{tabular}{ccc}
\hline \multirow{2}{*}{ KPM FI } & \begin{tabular}{c} 
Kolomogorov \\
Smirnov \\
\cline { 2 - 3 }
\end{tabular} & Sig. \\
\cline { 2 - 3 } & Pria & 0.006 \\
\hline
\end{tabular}

Pada tabel normalitas di Tabel XI Nampak bahwa nilai sig. KPM matematis mahasiswa yang mempunyai gaya kognitif FI pria sebesar $0.006<0.05$ sehingga diterima $\mathrm{H}_{0}$, bahwa data tidak normal. Begitu juga nilai sig. KPM matematis mahasiswa yang mempunyai gaya kognitif FI wanita sebesar $0.005<0.05$ sehingga $\mathrm{H}_{0}$ diterima, yang berarti data tidak normal. Karena data tidak normal digunakan uji homogenitas dengan uji lavene test.

TABEL XII

UJI HOMOGENITAS

\begin{tabular}{cccc}
\hline & & Levene & Sig. \\
\hline KPM FI & $\begin{array}{c}\text { Based on } \\
\text { Mean }\end{array}$ & 15.069 & 0.001 \\
\hline
\end{tabular}

Pada tabel homogenitas di tabel XII menunjukkan bahwa nilai sig. adalah $0.001<0.05$ sehingga $\mathrm{H}_{1}$ diterima yaitu bahwa data bersifat tidak homogen. Karena data tidak homogen dan tidak berdistribusi dengan normal sehingga digunakan uji parametric Mann-Whitney sebagai berikut:

TABEL XIII

UJI MANN WHITNEY TEST

\begin{tabular}{cc}
\hline & KPM \\
\hline Mann-Whitney U & 56.500 \\
\hline Sig. & 0.404 \\
\hline
\end{tabular}

Pada tabel uji Mann Whitney di tabel XIII Nampak bahwa nilai sig. sebesar $0,404>0.05$ sehingga $\mathrm{H}_{0}$ diterima yaitu tidak terdapat perbedaan KPM matematis mahasiswa yang mempunyai gaya kognitif FI berdasarkan gender. (Hardy, Bambang Hudiono, 2015) yang menyatakan bahwa tidak ada perbedaan KPM siswa pria dan wanita. Hasil itu secara umum telah memberikan gambaran bahwa gender (tanpa melihat apakah seseorang punya gaya kognitif FI atau FD) telah memberikan hasil bahwa tidak berpengaruh terhadap KPM matematika. Pada bagian ini lebih spesifik dihasilkan sebuah gambaran bahwa laki-laki dan perempuan yang mempunyai gaya kognitif FI ternyata tidak berpengaruh terhadap kemampuan pemecahan masalah matematika.

\section{SIMPULAN}

Berdasar hasil analisis terhadap data yang telah dilakukan sebelumnya maka dapat disimpulkan: (1) ada perbedaan KPM matematis mahasiswa yang mempunyai gaya kognitif 
field defendent dengan gaya kognitif field indefendent. (2) ada perbedaan KPM matematis berdasarkan tingkat kemandirian belajar pada mahasiswa. (3) tidak ada perbedaan KPM matematis berdasarkan gender mahasiswa. (4) tidak ada perbedaan KPM matematis mahasiswa yang mempunyai gaya kognitif field defendent berdasarkan gender. (5) tidak ada perbedaan KPM matematis mahasiswa yang mempunyai gaya kognitif field indefendent berdasarkan gender.

\section{DAFTAR PUSTAKA}

Badan Standar Nasional Pendidikan. (2010). Paradigma pendidikan nasional abad XXI. Jakarta: BSNP.

Bey, A. dan Narfin, L. (2013). Pengaruh Kemandirian Belajar Matematika Terhadap Hasil Pengaruh Kemandirian Belajar Matematika Terhadap Hasil. MIPMIPA, Vol. 12, No. 2, hal. $173-183$

Branca,N.A. (1980).ProblemSolvingasAGoal, ProccessandBasicSkill.Dalam Krulik\& RE.Reys(ed).ProblemSolvinginSchoolMathematic.Vir ginia: NCTMInc.

Brookhart, S. M. (2007). How to assess higher-order thinking skills in your classroom. Virginia USA: Alexandria.

Elliot, S. N., Kratochwill, T. R., Cook, J. L. \& Travers, J. F. (2000). Educational Psycology: Effective Teaching, Effective Learning, Third Edition. United States of America: McGraw-Hill Companies, Inc.

Degeng, N.S. (2013). Ilmu pembelajaran: klasifikasi variabel untuk pengembangan teori dan penelitian. Bandung: Arasmedia.

Dewi, Maulyana dan Huri Suhendri. 2017. Pengaruh Kemandirian dan Ketahanmalangan (Adversity Quotient) terhadap Kemampuan Pemecahan Masalah Matematika. Prosiding Diskusi Panel Nasional Pendidikan Matematika, e - ISSN: 2581 - 0812. (14/03/2018)

Hardy, Bambang Hudiono, M. R. (2015). Pengaruh Gender Dan Strategi Pembelajaran Terhadap Kemampuan Pemecahan Masalah Matematis Siswa, 1-14.

Jena, P. C. (2014). Cognitive styles and problem solving ability of under graduate students. International
Journal of Education and Psychological Research, 3(2), 71-76.

Kemenristekdikti. (2016). Peningkatan Kualitas Lulusan Pendidikan Tinggi yang Memiliki Daya Saing. Jakarta: Direktorat Jendral Pembelajaran dan Kemahasiswaan.

OECD. (2016). Programme forInternational Student

Assessment andtoaccessthefullsetofPISA2015.

www.oecd.org.edu/pisa

Pacific Policy Research Center. (2010). 21 st Century Skills for Students and Teachers. Research \& Evaluation, (August), 1-25.

Pasiak,Taufik.(2004).RevolusiIQ/EQ/SQ:AntaraNeurosains danal-Qur'an.Bandung:Mizan Pustaka

Sani, R. A. (2016). Penilaian autentik. Jakarta: Bumi Akasara.

Santrock, John W. (2007). Psikologi Pendidikan. Jakarta: Kencana Prenada Media Group.

Schunk, D. H. (1996). Learning theories. Printice Hall Inc., New Jersey (Vol. https://doi.org/10.1017/CBO9781107415324.004

Shi, C. (2011). A Study of the Relationship between Cognitive Styles and Learning Strategies. Higher Education Studies, 1(1), 20-26. https://doi.org/10.5539/hes.v1n1p20

Solso, R.L, Maclin, O.H., \& Maclin, M.K. (2008). Cognitive psycology. Pearson Education, Inc.

Sucipto. (2019). Pengaruh Collaborative Learning dan Gaya Kognitif terhadap Kemampuan Pemecahan Masalah dan Keterampilan Kolaboratif pada Mahasiswa. Disertasi tidak diterbitkan. Unesa Surabaya.

Trilling, B., \& Fadel, C. (2009). 21st Century Skills. JosseyBass, 256. https://doi.org/10.1145/1719292.1730970

Uno, H.B. (2006). Orientasi baru dalam psikologi pembelajaran. Jakarta: Bumi Aksara.

Wismath, S. L., \& Orr, D. (2015). Collaborative Learning in Problem Solving: A Case Study in Metacognitive Learning Collaborative Learning in Problem Solving: A Case Study in Metacognitive Learning. The Canadian Journal for the Scholarship of Teaching and Learning, 6(3). https://doi.org/10.5206/cjsotlrcacea.2015.3.10 